Original Research Paper

\title{
Analysis of the Protein Profile of Cassava Plantlets (Manihot esculenta Crantz.) Resistance to Fusarium Wilt Disease
}

\author{
${ }^{1,2}$ Endang Nurcahyani, ${ }^{3}$ Hardoko Insan Qudus and ${ }^{2}$ Ferina Evlin \\ ${ }^{I}$ Applied Biology Study Program, Faculty of Mathematics and Natural of Sciences, \\ University of Lampung, Bandar Lampung, Lampung, Indonesia 35145 \\ ${ }^{2}$ Biology Masters Study Program, Faculty of Mathematics and Natural of Sciences, \\ University of Lampung, Bandar Lampung, Lampung, Indonesia35145 \\ ${ }^{3}$ Chemistry Masters Study Program, Faculty of Mathematics and Natural of Sciences, \\ University of Lampung, Bandar Lampung, Lampung, Indonesia 35145
}

\section{Article history}

Received: 02-01-2021

Revised: 29-03-2021

Accepted: 08-04-2021

Corresponding Author: Endang Nurcahyani Applied Biology/Master Biology Study Program, Faculty of Mathematics and Natural of Sciences, University of Lampung, Bandar Lampung, Lampung, Indonesia Email: endang.nurcahyani@fmipa.unila.ac.id

\begin{abstract}
Fusarium wilt disease is still a production constraint in Cassava (Manihot esculenta Crantz.) cultivation. The disease is caused by the fungus Fusarium oxysporum ( $F o$ ), which to date has not been cured. It is expected that the use of varieties of cassava that are resistant to Fusarium wilt is an important alternative for disease control. Induced Resistance cassava research on Murashige and Skoog medium containing Fusaric Acid (FA) selective concentration has been done before and there were indications FA concentration tolerant to the selection of resistant plantlets in vitro. It is hoped that cassava plantlets that are resistant to FA will also be resistant to Fo. In previous studies, the inoculation of $F o$ fungal isolates on resistant cassava plantlets was carried out in vitro, followed by DNA pattern analysis compared to controls. The results of the DNA pattern analysis, in the form of a new (specific) DNA band that has a size of 550 bp (OPA_1) and 300 bp (OPA_10), are predicted to be candidates for RAPD markers for cassava resistance to $F o$. Based on the results of these previous studies, it is necessary to study more deeply in this study to ascertain whether the new DNA strand is really a peroxidase protein that causes cassava plantlets to be resistant to $F o$ by protein profile analysis. The results of protein profile analysis showed that the appearance of new protein bands (around $98 \mathrm{kD}$ ) indicated the formation of PR-protein (peroxidase) in cassava plantlets that were resistant to $F O$ and missing protein bands (around $65 \mathrm{kD}$ ) in cassava plantlets.
\end{abstract}

Keywords: Fusaric Acid, Fusarium oxysporum, In Vitro, Manihot esculenta, Protein Profile

\section{Introduction}

Cassava (Manihot esculenta Crantz.), is the third most important crop in the world and a source of food and tree income throughout the tropics. Cassava cultivation can provide sustenance to more than 500 million farmers (Eleazu et al., 2014; Amponsah et al., 2014). Cassava is an important food commodity in Indonesia and in the future this commodity will have a more strategic role in the lives of the people and the country's economy. Based on the area of harvest of food commodities, cassava ranks third after rice and corn, which are the three main sources of carbohydrates in the community (Fauzi et al., 2015). According to FAOSTAT (2019), Indonesia is the $6^{\text {th }}$ cassava producing country in the world after Nigeria, Congo, Thailand, Ghana and Brazil with a production of 14,586,693 tonnes. The center of cassava land in Indonesia is controlled by Lampung Province with production reaching 7,387,084 tonnes. This situation makes Lampung a third supplier of national cassava production from the national production of 21,801,415 tonnes (Badan Pusat Statistik, 2015).

One of the problems encountered in cultivating cassava is Fusarium wilt caused by the fungus Fusarium oxysporum. Arinze (2005) and Okigbo et al. (2009) reported that $50 \%$ of cassava tubers produced and harvested in Nigeria were lost due to disease. The main causes of decay of cassava include: Aspergillus flavus, 
Aspergillus niger, Botryodiplodia theobromae, Collectotrichum spp., Geotrichum candidum, Penicillium chrysogenum, Pennicillium digatum andFusarium oxysporum (Ogunleye and Ayansola, 2014; Raphaelet al., 2015; Gwa et al., 2015). This organism reduces the quantity and quality of the plant tubers (Amusa et al., 2003).

One alternative way of controlling disease that is safe for the environment, among others, is using resistant varieties. The development of cassava varieties that are resistant to Fusarium oxysporum can be carried out by in vitro selection methods, namely culturing explants in the form of tissues or organs on medium containing selective concentrations of fusaric acid (Nurcahyani, 2017; Nurcahyani et al., 2016a; 2016b; 2019a; 2019b; 2020).

Fusaric acid is a metabolite produced by several species of fungi from the genus Fusarium. This acid can be toxic (concentrations more than $10^{-5} \mathrm{M}$ ) thus inhibiting growth and culture regeneration, but at non-toxic concentrations (below $10^{-6} \mathrm{M}$ ) it actually helps to induce phytoalexin synthesis, a plant response forms to inhibit pathogenic activity (Bouizgarne et al., 2006).

The use of fusaric acid as a selective agent in in vitro selection can produce mutant cells or tissues that are insensitive to fusaric acid, so that after being regenerated into plants, they can produce strains resistant to pathogenic infections. The identification of mutants or variants that are insensitive to fusaric acid by in vitro selection has been carried out, among others, on the Sphatoglottis plicata (Nurcahyani et al., 2016a; 2016b), vanilla (Nurcahyani et al., 2012; 2014; Nurcahyani, 2017), Cassava (Nurcahyani et al., 2019a; 2019b), Phalaenopsis amabilis (L.) Bl. (Nurcahyani et al., 2020).

Research on Induced Resistance cassava with fusaric acid has been conducted before and found indications of tolerant fusaric acid concentrations for the selection of resistant plantlets in vitro. Inoculation of Fusarium oxysporum $(F o)$ fungal isolates on resistant cassava plantlets was carried out in vitro, followed by DNA pattern analysis compared to controls. The output of this study, in the form of a cassava mutant with a new (specific) DNA band measuring 550 bp (OPA_1) and 300 bp (OPA_10), is predicted to be a candidate RAPD marker for cassava resistance to $F o$. Based on the results of these studies, further study needs to be done to ascertain whether the new DNA strand is really a peroxidase protein that causes the cassava mutant to be resistant to Fo, namely by protein profile analysis. The special characteristics of cassava plantlet and related to resistance to fusarium wilt can be examined molecularly, that is, through the analysis of protein profiles using the SDSPAGE method. Comparison of protein bands formed by electrophoretic separation can be carried out to identify the gene product produced during Manihot esculenta plantlets selected by fusaric acid.
Based on the above background, more in-depth research is needed on the Induced Resistance of cassava plantlet resistant to Fusarium wilt disease, so that ultimately the long-term goal of this research will be achieved, namely the acquisition of cassava mutant varieties that are resistant to Fusarium oxysporum.

\section{Materials and Methods}

The tools and materials used in this research include Laminar Air Flow Cabinet (LAF), autoclave, freeze dryer, centrifuge, 0.2 and $1.5 \mathrm{~mL}$ microtube, shaker, electrophoresis tank, spectrophotometer, hot plate, microwave, PCR machine, UV transiluminator; Cassava plantlet (Manihot esculenta Crantz.), pure fusaric acid produced by Sigma chemical Co. \{Fusaric acid (5butylpicolinic acid) from Giberella fujikuroi\}, 70\% alcohol, solid Murashige and Skoog (MS) medium, Phosphate Buffer Saline (PBS), Bovin Serum Albumin (BSA), Bio-rad dye, reagent for SDS-PAGE, the protein ladder.

\section{Planting and Selection of Cassava Plants (Manihot esculenta Crantz.)}

Planting plants in Murashige and Skoog (MS) medium in culture bottles and added with Fusaric Acid (FA) with concentrations of 0 ppm (control), 60, 80, 100 and 120 ppm. Each concentration was carried out 5 times and each replication consisted of 2 cassava plants in each culture bottle. Plant selection was carried out for 30 days. At the end of the fourth week he was assessed to determine the concentration of fusaric acid yielding $\mathrm{LC}_{50}$ for in vitro cassava crop selection.

\section{Cassava Plantlets Protein Extraction}

Protein extraction was carried out by counting $1 \mathrm{~g}$ of plantlet leaves with each added $300 \mu \mathrm{L}$ of Phosphate Buffer Saline (PBS) (8.55 g/L NaCl, $1.33 \mathrm{~g} / \mathrm{L}$ $\mathrm{Na}_{2} \mathrm{HPO}_{4} .2 \mathrm{H}_{2} \mathrm{O}, 0.34 \mathrm{~g} / \mathrm{L} \mathrm{NaH} \mathrm{PO}_{4} . \mathrm{H}_{2} \mathrm{O}$. L) with a $\mathrm{pH}$ of 7 as extraction buffer and added with a protease inhibitor, then crushed using a mortar and pestle until homogeneous. The crushed sample was centrifuged at 13,000 rpm for 2 sec. Supernatant containing crude protein was taken and stored at $-20^{\circ} \mathrm{C}$ (Maniatis et al., 1982).

\section{Measurement of Protein Concentration}

After the crude protein is obtained, measurement of the protein concentration in each sample is carried out. Protein concentration was determined using the Bio-rad method (Bio-rad Assay). Determination of protein concentration was carried out by taking $2 \mu \mathrm{L}$ of protein samples using a micropipette plus $200 \mu \mathrm{L}$ of Bio-rad dye and $798 \mu \mathrm{L}$ of distilled water, then mixed by resuspension, then read by a spectrophotometer (Beckman, DU-65) at wavelength (OD $595 \mathrm{~nm}$ ). The 
protein concentration is known through the equation of the standard BSA protein standard curve function (Maniatis et al., 1982).

\section{Determination of the Molecular Weight of a Protein}

Determination of the Molecular Weight (MW) of protein was carried out using the SDS-PAGE method according to Maniatis et al. (1982). Electrophoresis at a voltage of 100 volts is carried out for 1.5 to $2.5 \mathrm{~h}$. Protein staining was carried out in a $0.10 \%$ solution of Coomasie Brilliant Blue, shaken with a shaker overnight. After staining, destaining is carried out to remove excess color by immersing the gel in a destaining solution $(50 \mathrm{~mL}$ distilled water, $40 \mathrm{~mL}$ methanol, $10 \mathrm{~mL}$ glacial acetic acid) until the gel becomes clear with separate bands from each other. The gel was then stored in $10 \%$ glacial acetic acid and then dried with a plate kit. The protein bands formed in the gel after electrophoresis were determined by their molecular weight $(\mathrm{kD})$. The molecular weight of the sample protein at each migration distance is obtained by extrapolating every distance of the desired sample protein band at the 2 migration distance of the protein marker bands that flank the sample protein band in question, so that a log of molecular weight is obtained, then the molecular weight of the protein band in question can be known.
To detect the presence of new (specific) proteins, it was done by comparing the protein profiles of Cassava leaflets that were not affected by fusaric acid with cassava plantlets induced by fusaric acid.

\section{Results and Discussion}

In this study, using cassava plantlet (Manihot esculenta Crantz.) In vitro and treated with various levels of fusaric acid. The fusaric acid used in this study contained five different concentration levels, namely 0 ppm (control), 60, 80, 100 and $120 \mathrm{ppm}$. The results of the selection of cassava plantlets that have been induced using fusaric acid with various different concentration levels are presented in Fig. 1.

Based on Fig. 1, visually, the plantlets in each treatment varied, especially seen from the poor morphological characters of the plantlets, namely small size, shoots and roots that were slightly formed and some were not formed at all. The visual appearance of the plantlets which were originally green turned pale green and brown (browning) after being treated with fusaric acid In browning-resistant planlets it occurs only at the base of the planlet in contact with the medium and does not extend to the ends. Plantlets that do not withstand browning quickly expand to all parts of the plantlet.

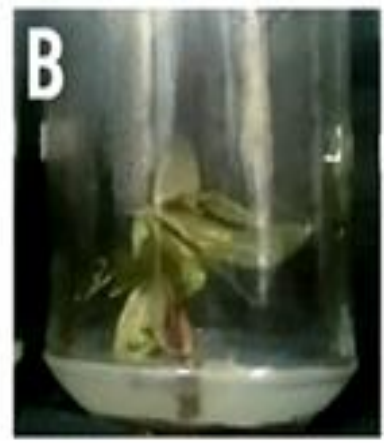

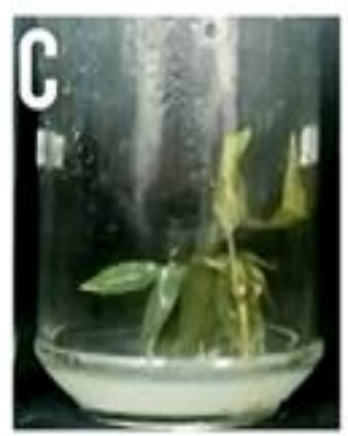
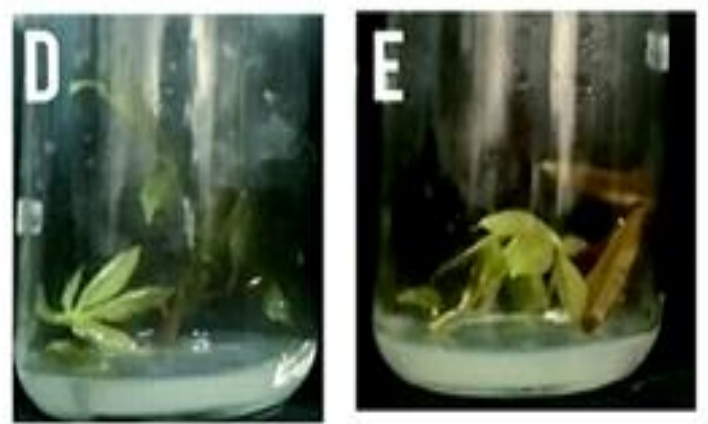

Fig. 1: Cassava plantlets with various concentrations of fusaric acid (A) 0 ppm "Control", (B) 60 ppm, (C) 80 ppm, (D) 100 ppm and (E) $120 \mathrm{ppm}$ 
Kuźniak (2001) stated that fusaric acid can affect the elimination of $\mathrm{O}_{2}^{-}$through quinone reduction which induces brown color and is thought to be associated with phenol transformation. The results of the phenol oxidation reaction are brown, so that the plantlets that have undergone phenol oxidation appear brown. If this oxidation reaction takes place continuously, the brown color will spread and diffuse into the medium and affect the growth of other plantlets that are cultured with the browning plantlets.

The specific character of Cassava plantlets and related to resistance to Fusarium oxysporum can be examined molecularly, namely through protein profile analysis using the SDS-PAGE method.

In principle, genes (DNA fragments) are transcribed into mRNA in the cell nucleus. Furthermore, the triplet base codon in mRNA is translated by the ribosome into amino acids. From this set of amino acids, a specific protein is formed. If there is a change in base and or structure in DNA/RNA, it is called a mutation which can be in the form of addition, deletion and substitution. As a result of this change in base, the expressed protein would certainly be different from those that did not undergo mutation. This concept will be discussed in Cassava's research with fusaric acid stress for resistance to Fusarium oxysporum. Plants treated with Fusaric acid will activate genes, including peroxidase, glucanase and chitinase genes (Saravanan et al., 2004).

The protein profile was obtained after the crude extract protein (concentration about $10 \mu \mathrm{g}$ ) was running by electrophoresis in 1D vertical gel (SDS-PAGE) for $2 \mathrm{~h}$, with a voltage of 90 volts. The protein banding pattern formed in the mutant candidates turned out to be different bands or bands compared to the control. This occurred in all samples both at fusaric acid treatment concentrations of 60, 80, 100 and 120 ppm (Fig. 2).

Based on Fig. 2, it was found that the expression of a new protein band with a molecular weight of about $98 \mathrm{kD}$ and a missing protein band with a molecular weight of 65 $\mathrm{kD}$ was found in the cassava Manihot esculenta Crantz. plantlet treated with $120 \mathrm{ppm}$ fusaric acid stress. From the protein profile analysis, it indicated that M. esculenta plantlets treated with $120 \mathrm{ppm}$ fusaric acid gave a different band than the control and fusaric acid treatment with a concentration of 60,80 and $100 \mathrm{ppm}$.

This shows that fusaric acid triggers the expression of peroxidase genes in the Cassava plantlets, so that their activity is higher and the protein bands are more clearly stained. Based on this, it is suspected that there has been a mutation in the promoter so that the band with molecular weight approximately $98 \mathrm{kD}$ can be indicated as a marker for Fusarium oxysporum resistant cassava plantlets.

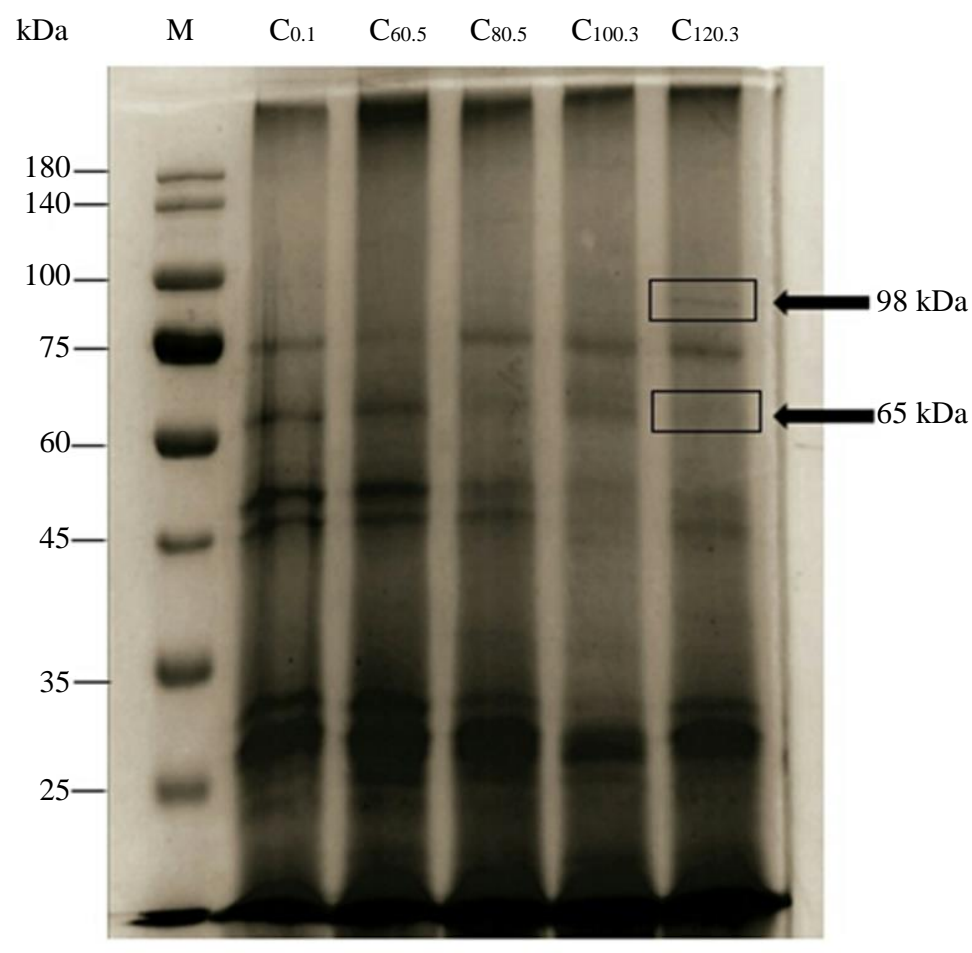

Fig. 2: Protein profile of cassava leaves (Manihot esculenta Crantz.) Induced by fusaric acid using SDS-PAGE 1D method. M = Marker. $\mathrm{C}_{0.1}=$ control, $\mathrm{C}_{60.5}=60 \mathrm{ppm}, \mathrm{C}_{80.5}=80 \mathrm{ppm}, \mathrm{C}_{100.3}=100 \mathrm{ppm}, \mathrm{C}_{120.3}=120 \mathrm{ppm}$. The arrow ()$=$ indicates a new protein band formed (approximately $98 \mathrm{kD}$ ) and disappeared (approximately $65 \mathrm{kD}$ ) in cassava plantlets that are resistant to Fusarium oxysporum 
According to Gunanti et al. (2010), the protein band thickness of the SDS-PAGE results illustrates the high and low concentration of a protein contained in the test sample. The induced resistance of cassava plantlets with fusaric acid treatment, one of the possibilities was due to the activation of the peroxidase gene which encodes the peroxidase enzyme and plays an important role in resistance to Fusarium oxysporum.

Research conducted by Ye and Ng (2002) on French beans has successfully isolated protein peroxidase and produced bands with molecular weight approximately 37 kD. In sorghum plants infected with Fusarium moniliforme, induction of resistance protein with molecular weight around 18 and $30 \mathrm{kD}$ and predicted as protein peroxidase (Kumari et al., 2006). A protein with molecular weight around $18.9 \mathrm{kD}$ has also been found by Ye and $\mathrm{Ng}$ (2009), which is an antifungal induction protein from Japanese takana seeds (Brassica juncea var. integrifolia). Meanwhile, Ye et al. (2011), found an antifungal protein with molecular weight around $30 \mathrm{kD}$ in red cabbage (Brassica oleracea). Nurcahyani et al. (2016a), in their research on vanilla (Vanilla planifolia) which was induced by fusaric acid and infected with Fusarium oxysporum, causing resistance induction with a molecular weight of about $18 \mathrm{kD}$ and predicted as protein peroxidase.

Genes need the right time and conditions to be expressed in the cycle of growth and development of plants. Entering a new stage of development, plants need the expression of several genes to produce proteins that play a role in every metabolic reaction in cells. In this case, it may be endogenously, the gene encoding the peroxidase enzyme is present in plantlets, but is only expressed when the condition is stressful, in this case fusaric acid. The expression of this peroxidase enzyme appears as a mechanism of resistance to fusaric acid stress and is also a resistance to Fusarium (Bouizgarne et al., 2006).

\section{Conclusion}

The character of cassava (Manihot esculenta Crantz.) plantlets which are resistant to Fusarium oxysporum can be proven molecularly, namely through protein profile analysis. The protein band (molecular weight approximately $98 \mathrm{kD}$ ) on SDS-PAGE $1 \mathrm{D}$ indicated the resistance to $M$. esculenta plantlets against Fusarium wilt disease. The protein with a molecular weight of about 98 $\mathrm{kD}$ is predicted to be a protein peroxidase, which plays a role in resistance to $F$. oxysporum. The perspective to ensure that the protein bands with molecular weight of about $98 \mathrm{kD}$ is protein peroxidase, it is necessary to isolate the protein, analyze its amino acid base by aligning it with the protein peroxidase sequence of other species, analysis of transient gene expression and/or Western blot analysis, this will be done at the next research stage.

\section{Acknowledgment}

Thanks the authors to the Institute for Research and Community Service through the BLU fund of University of Lampung, based on the Letter of Assignment of "Penelitian PASCASARJANA" 2020 Number of Contract: 1510/UN26.21/PN/2020 tanggal 24 Maret 2020.

\section{Author's Contributions}

Endang Nurcahyani: Participated in all experiments, coordinated the data-analysis and contributed to the writing of the manuscript.

Hardoko Insan Qudus: Coordinated the data analysis and translation of manuscript.

Ferina Evlin: Analyze protein profile data.

\section{Ethics}

The corresponding author confirms that all author have read and agree to the publish version of the manuscript. This article is original and contains unpublished material and no ethical issues involved.

\section{References}

Amponsah, S. K., Bobobee, E. Y., Agyare, W. A., Okyere, J. B., Aveyire, J., King, S. R., \& SarkodieAddo, J. (2014). Mechanical cassava harvesting as influenced by seedbed preparation and cassava variety. Applied Engineering in Agriculture, 30(3), 391-403.

https://doi.org/10.13031/aea.30.10495

Amusa, N. A., Adigbite, A. A., Muhammed, S., \& Baiyewu, R. A. (2003). Yam diseases and its management in Nigeria. African Journal of Biotechnology, 2(12), 497-502. https://doi.org/10.5897/AJB2003.000-1099

Arinze, A. E. (2005). Plant Pathology and Post-harvest Food Loss. An Inaugural Lecture Series, 43, 29-72. https://www.uniport.edu.ng/files/43InauguralLectur e.pdf

Badan Pusat Statistik. 2015. Produksi Ubi Kayu MenurutProvinsi (ton), 1993-2015. Badan Pusat Statistik.

https://www.bps.go.id/dynamictable/2015/09/09\%2 000:00:00/880/produksi-ubi-kayu-menurut-provinsiton-1993-2015.html

Bouizgarne, B., El-Maarouf-Bouteau, H., Frankart, C., Reboutier, D., Madiona, K., Pennarun, A. M., ... \& Bouteau, F. (2006). Early physiological responses of Arabidopsis thaliana cells to fusaric acid: toxic and signalling effects. New Phytologist, 169(1), 209-218. 
https://doi.org/10.1111/j.1469-8137.2005.01561.x

Eleazu, O. C., Eleazu, K. C., \& Kolawole, S. (2014). Use of indigenous technology for the production of high quality cassava flour with similar food qualities as wheat flour. Acta Scientiarum Polonorum Technologia Alimentaria, 13(3), 249-256. https://doi.org/10.17306/J.AFS.2014.3.3

FAOSTAT. (2019). Countries by commodity. http://www.fao.org/faostat/en/\#rankings/countries_b y_commodity

Fauzi, M., Kardhinata, E. H., \& Putri, L. A. P. (2015). Identifikasi dan inventarisasi genotip tanaman ubi kayu (Manihot esculenta Crantz) di Kabupaten Serdang Bedagai Sumatera Utara. Online Journal of Agrotechnology, 3(3), 1082-1088.

https://media.neliti.com/media/publications/105384ID-identifikasi-dan-inventarisasi-genotip-t.pdf

Gunanti, M., Ulia, F., \& Sri, D. (2010). Characterization of Larnea cyprinacea protein using theSDS-PAGE electrophoresis method. Fisheries and Marine Scientific Journal, 2(1), 61-66. https://ejournal.unair.ac.id/JIPK/article/view/11669

Gwa, I. V., Bem, A. A., \& Okoro, J. K. (2015). Yams (Dioscorea rotundata Poir and D. alata Lam.) fungi etiology in Katsina-ala local government area of Benue state, Nigeria. Journal of Phytopathology and Plant Health, 3, 38-43.

https://afribary.com/works/yams-dioscorea-rotundatapoir-and-d-alata-lam-fungi-etiology-in-katsina-alalocal-government-area-of-benue-state-nigeria

Kumari, R. S., Chandrashekar, A., \& Frekeriksen, R. A. (2006). Levels of Three Antifungal Proteins During Development, Germination and In Response to Fungal Infection in Grain Sorghum. African Crop Science Journal, 4(1), 79-87. http://www.bioline.org.br/abstract?cs96043

Kuźniak, E. (2001). Effects of fusaric acid on reactive oxygen species and antioxidants in tomato cell cultures. Journal of Phytopathology, 149(10), 575-582. https://doi.org/10.1046/j.1439-0434.2001.00682.x

Maniatis, T., Fritsch, E. F., \& Sambrook, J. (1982). Molecular Cloning. A Laboratory Manual. New York: Cold Spring Harbor Laboratory, ISBN-10: 0879691360.

Nurcahyani, E. (2017). DNA Pattern Analysis of Vanilla planifolia Andrews Plantlet which Resistant to Fussarium oxysporum f. sp. vanillae. World Journal of Pharmaceutical and Life Sciences WJPLS, 3(4), 27-34. http://repository.lppm.unila.ac.id/6054/

Nurcahyani, E., Agustrina, R., \& Handayani, T. T. (2016a). The Protein Profile of the Plantlets of Spathoglottis plicata B1. Induced Resistance to Fusarium oxysporum. Journal of Plant Sciences, 4(5), 102-105.

http://repository.lppm.unila.ac.id/1075/
Nurcahyani, E., Agustrina, R., Suroso, E., \& Andari, G. (2016b). Analysis of Peroxidase Enzyme and Total Phenol from Ground Orchid (Spathoglottis plicata Bl) as Result of the In Vitro Fusaric Acid Selection Toward To Fusarium oxysporum. International Journal of Applied Agricultural Sciences, 2(6), 79-82. https://doi.org/10.11648/j.ijaas.20160206.11

Nurcahyani, E., Hadisutrisno, B., Sumardi, I.,\& Suharyanto, E. (2014). Identification ofVanilla Planlet Strains (Vanilla planifolia Andrews) Resistant to Fusarium oxysporum infection $\mathrm{f}$. Sp. vanillae In Vitro Selection Results With Fusaric Acid. Proceedings of the National Seminar: "Disease Control in Environmentally Friendly Agricultural Plants". Indonesian Association of Phytopathology, Komda Joglosemar-Faculty of Agriculture UGM. http://repository.lppm.unila.ac.id/id/eprint/32518

Nurcahyani, E., Irawan, B., Sumardi, Sari, E. Y., \& Sari, T.L. (2019a). DNA Pattern AnalysisCassava plantlet (Manihot Esculenta Crantz.) Induced Resistance Results Against Fusarium oxysporum. Journal of Tropical Upland Resources, 1(1), 93-102. https://jtur.lppm.unila.ac.id/jtur/article/view/14

Nurcahyani, E., Sumardi, S., \& Irawan, B. (2019b). In Vitro Study: Induced Resistance Of Cassava (Manihot esculenta Crantz.) Plantlet Against Fusarium oxysporum Based on Analysis of Phenol Content. WJPLS, 5(2), 195-198.

http://repository.lppm.unila.ac.id/11239/

Nurcahyani, E., Sumardi, I., Hadisutrisno, B., \& Suharyanto, E. (2012). Emphasis on the Development of Vanilla Stem Rot Disease (Fusarium oxysporum $\mathrm{f}$. Sp. Vanillae) through In Vitro Fusaric Acid Selection. Journal HPT Tropical., 12(1), 12-22. http://jhpttropika.fp.unila.ac.id/index.php/jhpttropika/ article/view/112

Nurcahyani, E., Sumardi, Qudus, H.I., Wahyuningsih, S., Sholekhah, \& Palupi, A. (2020). InVitro Selection Phalaenopsis amabilis (L.) Bl. Plantlets Result of Induced Resistance With Fusaric Acid. World Journal of Pharmaceutical and Life Sciences. WJPLS, 6(2), 25-28.

https://www.wjpls.org/admin/assets/article_issue/48 012020/1580434679.pdf

Ogunleye, A. O., \& Ayansola, O. T. (2014). Studies of some isolated rot-causing mycoflora of yams (Dioscorea spp.). American Journal of Microbiology and Biotechnology, 1(1), 9-20.

https://www.academia.edu/31689661/Studies_of_so me_isolated_rot_causing_mycoflora_of_yams_Dios corea_spp

Okigbo, R. N., Putheti, R., \& Achusi, C. T. (2009). Postharvest deterioration of cassava and its control using extracts of Azadirachta indica and Aframomum melegueta. E-Journal of Chemistry, 6(4), 1274-1280. https://doi.org/10.1155/2009/680519 
Raphael, O. N., Ebere, E. C., Kingsley, A. C., Chidiebere, I. R., Chidi, O. B., Nsikak, A. S., ... \& Confidence, I. A. (2015). Control of white yam (Dioscorea rotundata) rot pathogen using peel extract of water yam (Dioscorea alata). Advances in Applied Science Research, 6(10), 7-13.

https://www.imedpub.com/articles/control-ofwhite-yam-dioscorea-rotundata-rot-pathogenusing-peel-extract-ofwater-yam-dioscoreaalata.pdf

Saravanan, T., Bhaskaran, R., \& Muthusamy, M. (2004). Pseudomonas fluorescens induced enzymological changes in banana roots $(\mathrm{Cv}$. Rasthali) against Fusarium wilt disease. Plant Pathology Journal 3, 72-80. https://doi.org/10.3923/ppj.2004.72.80
Ye, X. J., Ng, T. B., Wu, Z. J., Xie, L. H., Fang, E. F., Wong, J. H., ... \& Zhang, Y. B. (2011). Protein from red cabbage (Brassica oleracea) seeds with antifungal, antibacterial and anticancer activities. Journal of Agricultural and Food Chemistry, 59(18), 10232-10238. https://doi.org/10.1021/jf201874j

Ye, X. Y., \& Ng, T. B. (2002). Isolation of a novel peroxidase from French bean legumes and first demonstration of antifungal activity of a non-milk peroxidase. Life Sciences, 71(14), 1667-1680. https://doi.org/10.1016/S0024-3205(02)01925-2

Ye, X., \& Ng, T. B. (2009). Isolation and characterization of juncin, an antifungal protein from seeds of Japanese Takana (Brassica juncea Var. integrifolia). Journal of Agricultural and Food Chemistry, 57(10), 4366-4371. https://doi.org/10.1021/jf8035337 